\title{
Argentine Association of Materials Joins IUMRS
}

The SAM-Asociación Argentina de Materiales (Argentine Association of Materials) has joined the International Union of Materials Research Societies. SAM has its origin in the former Sociedad Argentina de Metales (Argentine Society of Metals), the Society responsible for the initials SAM still used by the Association. SAM was created as a result of the initiative of a group of professionals and researchers in metallurgy during the Foundation Assembly held in the Facultad de Ciencias Exáctas, Fisicas y Naturales of the University of Buenos Aires, on December 20, 1955. As documented in the records of the assembly, the purpose was "to constitute an association which has as its objectives:

1. To promote scientific and technological knowledge in metallurgy; to foment, to coordinate, and to promote its research and teaching; to involve professionals dedicated to this discipline or interested in its development; and to tend to the maintaining of a high professional level in this field among its members.

2. To develop a center of bibliographic reference, involving other Institutes, both national and international.

3. To exclude all concerns which could imply political, trade-union, religious, or commercial character."

The first Council was elected at the assembly, and membership during the first year reached 61 .

During 1956, a series of postgraduate courses, taught by professionals from Argentina and other countries, were initiated. Among the most significant titles were "Metallurgy," "Metallographic Methods," "Metallurgy of Welding by Voltaic Arc," and "Thermal Treatment of Steels."

In 1957 a series of conferences on metallurgy were held at a number of universities and professional associations in Argentina, including the University of Buenos Aires, the National University of La Plata, the National Atomic Energy Commission, and the Argentine Center of Engineers.

In the following year, links with foreign organizations with similar objectives were initiated. These included the American Institute of Mining, Metallurgical and Petroleum Engineers; the American Iron and Steel Institute; the American Society for Metals (all in the United States); Associaçao Brasileira de Metais (Brazil); Associacione Italiana di Metallurgia (Italy); Instituto del Hierro y del Acero (Spain); Societé Française de Metallurgie (France); The Institute of Metals and The Iron and Steel Institute (United Kingdom); and Verein Deutsche Eisenhüttenleute (Germany).

As a result of these links, many specialized scientific journals (e.g., the Journal of the Iron and Steel Institute, Journal of the Institute of Metals, Metal Progress, ABM Notiziario y Boletim, La Metallurgia Italiana, La Fondaria Italiana, and Instituto del Hierro $y$ del Acero) were regularly received by the SAM membership.

In September 1959 the first Jornadas Metalúrgicas Argentinas (Argentine Metallurgical Meeting) was organized, with a large number of participants from Argentina and from other countries, including France, Germany, the United States, Brazil, Belgium, Sweden, Chile, Venezuela, England, Australia, and Russia. More than a hundred scientific papers were presented. Since then, similar Meetings were organized every year. At these Meetings, research and development papers are presented. Early on, the papers were almost exclusively related to metallurgy but as time went on they gradually extended to other materials. The papers presented were published as Proceedings and distributed to the participants during the meeting.

At the end of the 1950s, the number of members increased to over 300 , stimulated by official visits of SAM Council members to other similar organizations from Europe and the United States, principally during scientific meetings.

As an example of the contribution to the development of industrial metallurgy in Argentina, SAM founded the Comité de Normalización Metalúrgica (Metallurgical Normalization Committee) known as CONOME. This organization is dedicated to the promotion, study, and discussion of quality norms related to metallurgical production in Argentina in collaboration with the Instituto Argentino de Normalización (Argentina Institute of Materials Normalization) known as IRAM, and in agreement with common regulations corresponding to Comisión Panamericana de Normas Técnicas (Pan-American Committee of Technical Norms) known as COPANT; Asociación Latinoamericana de Libre Comercio (Latino-American Association of Free-Trade) known as ALALC, and Brussels Code.

During the following years, SAM has continued organizing postgraduate courses and seminars, many of which have been given in collaboration with other institutions from Argentina and other countries. These seminars have covered fields such as solidification, deformation, phase transformation, manufacturing processes, and methods of characterization and analysis of structures and properties. These courses and seminars have enjoyed the active participation of industries which have collaborated in special practical topics, thus bridging the gap between scientific and academic activity and industrial activities, leading toward improved complementary information related to world progress in metallurgy. Along these lines, SAM promoted the creation of the Instituto Superior de Estudios Metalúrgicos (ISEM) in 1966. The ISEM goal was to improve professional preparation, in different areas of metallurgy, for various disciplines dedicated to industrial activities in metallurgy. At this time, several technical subcommittees were created for the purpose of training professionals in specific fields.

Starting in 1959, SAM published the magazine Metalurgia Moderna (Modern Metallurgy). This publication had three sections: one dedicated to news-related SAM activities, another dedicated to articles on scientific research and development, and another dedicated to industrial activities. Despite its irregular publication period (nonperiodic), 36 issues were published between 1959 and 1975. Metalurgia Moderna has received recognition from the United Nations (UNESCO), The Library of Congress (Washington, USA), and the Institute of Scientific Information of the URSS Academy of Sciences (Russia).

The SAM annual meetings, the postgraduate courses, and the Metalurgia Moderna publications were SAM's most significant activities from 1955 until 1993. In March of 1993, taking into account the growing importance of other types of materials and following the worldwide tendency to transform metallurgic associations into materials associations, the Sociedad Argentina de Metales became the foundation of the Asociación Argentina de Materiales (Argentine Association of Materials). During the creation of the Asociación Argentina de Materiales, in recognition of the 38 years of service of the former Society, the new Association is known under the original initials "SAM." Presently, SAM is listed under IUMRS as "MRS-Argentina."

Since its creation, SAM-Asociación Argentina de Materiales has continued with its activities, organizing annual meetings, and publishing the Boletin de la Asociación Argentina de Materiales (Argentine Association of Materials Bulletin).

SAM-Asociación Argentina de Materiales currently has more than 400 members. The Association includes members from 
other countries within South America, maintaining SAM-Delegations in Brazil and Chile, countries from which many researchers and professionals habitually attend the annual SAM meetings.

Jorge N. Feugeas (Instituto de Física Rosario, IFIR) is the president of SAM, Liliana Nosei (Instituto de Macánica Apli- cada y Estructuras, Universidad Nacional de Rosario) is Secretary, Jorge $O$. Tormo (Instituto Argentino de Siderurgia) is Treasurer, and Lucio Iurman (Universidad Nacional del Sur) is Past-President. The Council members are Carlos Gonzalez Oliver (Comisión Nacional de Energía Atómica), Juan E. Perez Ipiña (Universidad del Comahue), José Ovejero Garcia (Comisión Nacional de Energía Atómica), and Ricardo Romero (Universidad Nacional del Centro de la Provincia de Buesnos Aires).

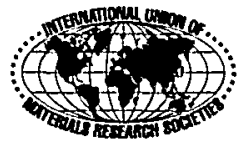

\section{MRS NEWS}

\section{Frans Spaepen Receives 1998 Woody Award}

Frans Spaepen, Gordon McKay Professor of Applied Physics at Harvard University and Director of Harvard's Materials Research Laboratory, is the recipient of the 1998 Materials Research Society Woody Award. Robert J. Nemanich, 1998 MRS president, made the presentation to Spaepen at the 1998 MRS Fall Meeting in Boston.

The Woody Award, which recognizes "outstanding service and dedication on behalf of MRS as exemplified by Woody White, MRS president, 1984," is bestowed annually by the Society president to a single individual for his or her extraordinary contributions to MRS. Spaepen's service includes over five consecutive years as chair of the Program Committee, which is a leadership role critical to the development of the Society's technical meetings.

"Our meetings are different from any other Society's," said Nemanich. "Our programs start from a clean slate and are reinvented with every meeting. Frans understands this process. His broad knowledge of materials research and the way he is able work with the meeting chairs to bring ideas together in developing our programs inspire our confidence in his leadership."

1997 MRS president Robert Hull echoed Nemanich's words, praising Spaepen's "encyclopedic knowledge of materials science" and calling him "one of the leading materials researchers in the world today."

"Frans has played an enormous role in

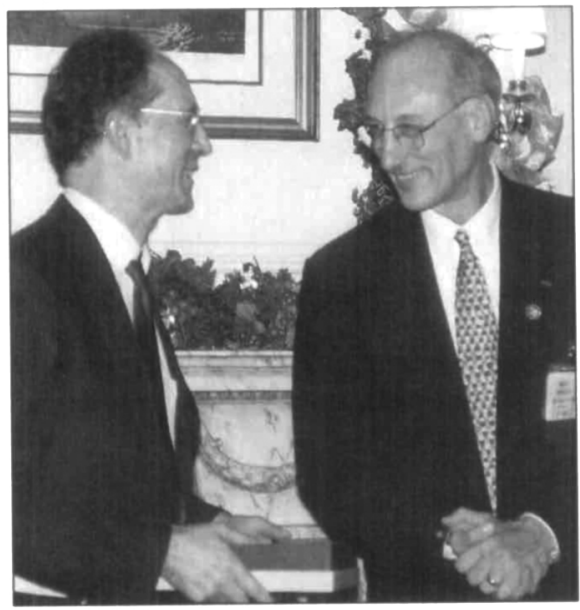

Frans Spaepen (left) receives the 1998 Woody Award, presented by Materials Research Society president Robert $J$. Nemanich (right).

the success of MRS meetings for many years," said Hull. "He is diplomatic and persuasive, enormously efficient, competent, and effective in his role as chair of the Program Committee. He's an absolute joy to work with."

In addition to his service to MRS as chair of the Program Committee, Spaepen has contributed to the Society as a Symposium Organizer (1985, 1987), a Meeting Chair (Fall 1990), and as a member of Council (1986-1988 and 1990-1992). "During his years on Council, Frans was widely re- spected for his thoughtful counsel," said Julia M. Phillips, 1995 MRS president, who served with Spaepen as a fellow Councillor in the early $1990 \mathrm{~s}$.

A native of Flanders, Spaepen received an undergraduate degree in metallurgical engineering from the University of Leuven and a PhD degree in applied physics from Harvard University in 1975, where he has remained ever since. His research interests include structure, diffusion, and mechanical properties of amorphous metals and semiconductors; crystal nucleation and glass formation; structure and thermodynamics of solid-liquid and solid-solid interfaces; and the formation and mechanical properties of thin films and multilayers.

Spaepen is a Fellow of the American Physical Society and the Minerals, Metals, and Materials Society, and he currently serves on the Science \& Technology Steering Committee for Brookhaven National Laboratory. He is a member of the editorial board of the Journal of Applied Physics and Applied Physics Letters.

"I was delighted to learn that the 1998 Woody Award was bestowed on Frans Spaepen," said Phillips. "Under Frans' leadership, the MRS meetings have grown tremendously, both in size and in technical breadth. Keeping balance among the various MRS 'constituencies' in programming and preserving the MRS 'feel' of the meetings in the face of such growth have been a major accomplishment of which Frans and the rest of the Program Committee should be very proud."

\section{MRS BULLETIN SEEKS IUMRS NEWS ON}

\section{- Upcoming Meetings \\ - Important Technical Developments \\ - Policy Issues}

\author{
- Conference Reports \\ - Research News \\ - Educational Initiatives
}

MRS Bulletin, Materials Research Society

506 Keystone Drive, Warrendale, PA $15086-7573$ USA

E-mail: bulletin@mrs.org or gabrielle.long@nist.gov; Fax: 724-779-8313 